\title{
Brazilian Legislation on Executive Power: Provisory or Permanent Measures?
}

Dr. Murillo de Oliveira Dias*

Coordinator and Professor, Fundação Getulio Vargas, Brazil

DOI: $10.36348 /$ SIJLCJ.2019.v02i10.007

| Received: 21.10.2019 | Accepted: 28.10.2019| Published: 30.10.2019

*Corresponding author: Dr. Murillo de Oliveira Dias

\section{Abstract}

In 1988, the National Constituent Assembly promulgated the Brazilian Constitution, creating the Provisional Measure (MP) through Art. 62, which is a single act of the President of the Republic, due to urgency and relevance of the subject, with an immediate force of law, for a period not superior to 60 days. In this article, N=1,512 MPs, issued from 1988 to 2019, were analyzed. Key findings pointed out 1,160 MPs converted into Laws (77 percent conversion tax), 67 MPs in process, from which $\mathrm{N}=51 \mathrm{MPs}$ are still in force for 18 years. This inconsistency is given by the Constitutional Amendment 32, issued on September 11, 2001, which altered the termination clause over time from Art. 62, paragraph 1st, under investigation. The implications are potential legal uncertainty arising from disparities, regarding provisional measures that became permanent, until appreciated by the Brazilian Congress. Case analysis and discussion complete the present work.

Keywords: Provisory Measure, Federal Constitution, Constitutional Amendment, Brazilian Legislation.

Copyright @ 2019: This is an open-access article distributed under the terms of the Creative Commons Attribution license which permits unrestricted use, distribution, and reproduction in any medium for non-commercial use (NonCommercial, or CC-BY-NC) provided the original author and source are credited.

\section{INTRODUCTION}

This study presents an extensive investigation of the Brazilian Provisory Measures (Medidas Provisórias, or MPs, in Brazilian Portuguese), as the unit of analysis [1].

Provisory Measures are exclusive acts of the Brazilian chief of the executive power, created by the Constitution 1988, Art. 62, "with an immediate force of law, without the participation of the Legislative Power, due to urgency and relevance of the subject, for a period not superior to 60 days" [2]. Nevertheless, evidence was found that approximately five percent of the overall $\mathrm{N}=1,512$ MPs are still in force after the termination period. In other words, provisory became, became longlife, permanent ones. $\mathrm{N}=51 \mathrm{MPs}$ are still in force for eighteen years. Such MPs are investigated in this case study.

MP 2.162-72, for instance, from August 23, 2001, ruling the issuance of National Treasury Notes NTN for the capital increase of the Banco do Brasil S.A., was re-issued 72 times, on a monthly basis, from March 14, 1996 (initially MP 1.367 - MPs sometimes changed their identification number, for distinct classification purposes), since then in process, with full legal force for 18 years.
The answer to the discrepancies studied here lies in the Constitutional Amendment 32 (CA32), issued on September 11, 2001 [5].

The "Citizen Constitution", as became known Constitution 1988, was issued on October 5, 1988, with 117 articles, and Amended 102 times, from 1988 to 2019. In this research, only Art. 62 is under investigation, in which MPs are ruled [2], together with CA32, regarding Art. 62 [5].

In the next sections, methods and limitations are presented. Case analysis, discussion, implications and future research complete the current study.

The "Citizen Constitution", as became known Constitution 1988, was issued on October 5, 1988, with 117 articles, and Amended 102 times, from 1988 to 2019. In this research, only Art. 62 is under investigation, in which MPs are ruled [2], together with CA32, regarding Art. 62 [5].

In the next sections methods and limitations are presented. Case analysis, and discussion complete the current study. 


\section{METHODS AND LIMITATIONS}

This study is qualitative, inductive reasoning, multi-method approach interpretive. It compiled a single descriptive case study with extensive archival research. The unit of analysis is the Brazilian Provisional Measures [1].

This research is limited to Federal Constitution 1988, Art. 62 [2], and Constitutional Amendment 32 [5], regarding Art. 62 modification. Archival research was conducted solely upon the Brazilian Congress database [6].

Moreover, this study is limited also by the Brazilian Federative Republic government system. Other government systems are not part of this study and should be investigated in separate.

Finally, this research is limited to the MPs issued from 1988 to October 2, 2019. Other legal instruments or different periods are not investigated here.

\section{FEDERAL CONSTITUTION 1988}

Provisory Measure (MP), is a legal dispositive, exclusive to the executive power. According to the Brazilian Constitution 1988, Art. 62, Title IV, Chapter I (Legislative Power), Section VIII (Legislative Process), subsection III, "In case of relevance and urgency, the President of the Republic may adopt provisional measures, with force of law, and shall submit them immediately to the National Congress" [2].

However, MPs are limited in scope, as originally worded by Art. 62, § 1:

- Nationality, citizenship, political rights, political parties and electoral law;

- Criminal law, criminal and civil procedural law;

- Organization of the judiciary and the public prosecutor, the career and guarantee of its members;

- Multiannual plans, budget guidelines, budget and additional and supplementary credits, except as provided in art. 167, §3 [2]

The tax increase is prevented by $\S 2$ - finally, $\S 12$, Art. Sixty-two issued "the provisional measure shall be fully effective until the draft is sanctioned or vetoed" [2] CA 32 has altered the Art. 62, as demonstrated in the next section.

\section{CONSTITUTION AMENDMENT 32}

Constitution Amendment 32 (CA32) was issued on September 11, 2001. CA32 altered the following articles from Federal Constitution: (a) $1^{\circ}$, (b) 48, (c) 57, (d) 61, (e) 62, (f) 64, (g) 66, (h) 84, (i) 88, and finally (j) 246. In this research, only art. 62 is studied. Article 62 has been altered on its caput and in $\S$ 1 :
CA 32, Art. 62. Caput, the following sentence was eliminated (in red)

Em caso de relevância e urgência, o Presidente da República poderá adotar medidas provisórias, com força de lei, devendo submetê-las de imediato ao Congresso Nacional., que, estando em recesso, será convocado extraordinariamente para se reunir no prazo de cinco dias $[2,5]$

Directly translated, Art. 62 from CA 32 remained as follows: "In case of relevance and urgency, the president of the Republic should adopt provisory measures, with the full force of law, submitting them to the National Congress."

The sentence in red was suppressed: "(..) even being in recess, should be extraordinarily summoned, in five days. Therefore, CA32 removed the possibility for congress extraordinary convocation within the recess.

CA 32, sole paragraph became $\S 1$ :

$\S 1$ Parágrafo único. ÉAs vedada a edição de medidas provisórias sobreperderão matéria:eficácia, desde a edição, se não forem convertidas em lei no prazo de trinta dias, a partir de sua publicação, devendo o Congresso Nacional disciplinar as relações jurídicas delas decorrentes.

In sum, the expiration period of 30 days, counting after the MP publication, was, by CA 32, suppressed from the original Art. 62, from Federal Constitution 1988. In the following sections, the consequences of such an Amendment will be analyzed.

\section{PROVISORY MEASURES (1988 - 2019)}

For the purposes of this research, $\mathrm{N}=1,512$ MPs has been investigated, from November 4, 1988 (MP 10) October 2, 2019 (MP 897). Out of these, 1,160 MPs were converted in laws (77 percent), 312 were rejected, terminated (33 percent), or are in the process 67 (approximately 4.5 percent).

First, Figure 1 illustrates the MPs issued before and after CA 32:

\begin{tabular}{|c|c|c|c|c|}
\hline \multicolumn{2}{|c|}{ Constitutional Ammendment 32} & \multirow{2}{*}{$\begin{array}{l}\text { MPs } \\
\text { (a) }\end{array}$} & \multirow{2}{*}{$\begin{array}{c}\text { MPs Re- } \\
\text { editions } \\
\text { (b) }\end{array}$} & \multirow{2}{*}{$\begin{array}{c}\text { Total } \\
(\mathrm{c}=\mathrm{a}+\mathrm{b})\end{array}$} \\
\hline MPs & Period & & & \\
\hline Before & $1988-2001$ & 615 & 9.588 & 10.203 \\
\hline After & $2001-2019$ & 897 & 0 & 897 \\
\hline \multicolumn{2}{|c|}{ Total } & 1.512 & 9.588 & 11.100 \\
\hline
\end{tabular}

[6]

Observe in Figure-1 that before the Constitutional Amendment 32 (CA 32), from 1988 to 
2001, the number of MP re-issuance or re-editions reached 9,588 MPs, and after CA 32, dropped to zero.

Figure-2 depicts the number of MPs converted into Laws, before and after the CA 32:

\begin{tabular}{ccccc}
\hline Constitutional Ammendment 32 & MPs & $\begin{array}{c}\text { MPs } \\
\text { converted } \\
\text { into Laws } \\
\text { MPs }\end{array}$ & Period & $\begin{array}{c}\text { Conversion } \\
\text { rate }(\%)\end{array}$ \\
Before CA 32 & $1988-2001$ & 615 & 479 & $78 \%$ \\
After CA 32 & $2001-2019$ & 897 & 681 & $76 \%$ \\
\hline \hline & & & & \\
\hline
\end{tabular}

Fig-2: MPs converted into Laws. Source: Brasil, 2019 [6]

Note in Figure-2 that the conversion tax decreased slightly after the CA 32 (2 percent) in comparison to both periods (before and after CA 32). Nevertheless, the number of Congress sessions for MP appreciations decreased dramatically; thus, optimizing National Congress performance on MPs. Once MPs are initially, acts of the executive power, not the legislative branch, they might be seen as interference from the executive on congressional matters.

Figure 3 illustrates the MPs rejected and in process, before and after CA 32 :

\begin{tabular}{|c|c|c|c|c|c|}
\hline \multicolumn{2}{|c|}{ Constitutional Ammendment 32} & \multirow{2}{*}{$\begin{array}{l}\text { MPs } \\
\text { (a) }\end{array}$} & \multirow{2}{*}{$\begin{array}{c}\text { MPs } \\
\text { Rejected } \\
\text { (f) }\end{array}$} & \multirow{2}{*}{$\begin{array}{c}\text { Rejection rate } \\
\qquad \begin{array}{c}(\%) \\
(\mathrm{g}=\mathrm{f} / \mathrm{a})\end{array}\end{array}$} & \multirow{2}{*}{$\begin{array}{c}\text { In } \\
\text { Process }\end{array}$} \\
\hline MPs & Period & & & & \\
\hline Before CA 32 & $1988-2001$ & 615 & 136 & $22 \%$ & 51 \\
\hline After CA 32 & $2001-2019$ & 897 & 216 & $24 \%$ & 16 \\
\hline \multicolumn{2}{|c|}{ Total } & 1.512 & 352 & $23 \%$ & 67 \\
\hline
\end{tabular}

Fig-3: MPs rejected and in process. Source: Brasil, 2019 [6]

Out of the $\mathrm{N}=67$ total MPs in process, before the CA 32, N=51 MPs remain in force since 2001. After the CA 32, 16 MPs remain in process; however, they are still in due time.

From 1988 to 2019, eight Brazilian presidents took office, as shown in Figure-4, as follows:

\begin{tabular}{|c|c|c|c|c|}
\hline $\begin{array}{l}\text { Succesion } \\
\text { line }\end{array}$ & President & MPs & $\begin{array}{l}\text { MPs converted } \\
\text { into Laws }\end{array}$ & $\begin{array}{l}\text { Conversion } \\
\text { rate (\%) }\end{array}$ \\
\hline $30^{\circ}$ & Tancredo Neves & 0 & 0 & 0 \\
\hline $31^{\circ}$ & José Sarney & 121 & 101 & $83 \%$ \\
\hline $32^{\circ}$ & Fernando Collor & 96 & 73 & $76 \%$ \\
\hline $33^{\circ}$ & Itamar Franco & 78 & 67 & $86 \%$ \\
\hline $34^{\circ}$ & $\begin{array}{l}\text { Fernando Henrique } \\
\text { Cardoso }\end{array}$ & 422 & 322 & $76 \%$ \\
\hline $35^{\circ}$ & $\begin{array}{l}\text { Luis Inacio Lula da } \\
\text { Silva }\end{array}$ & 419 & 366 & $87 \%$ \\
\hline $36^{\circ}$ & Dilma Roussef & 222 & 156 & $70 \%$ \\
\hline $37^{\circ}$ & Michel Temer & 126 & 70 & $56 \%$ \\
\hline $38^{\circ}$ & Jair Messias Bolsonaro & 28 & 5 & $18 \%$ \\
\hline & Total & 1.512 & 1.160 & $77 \%$ \\
\hline
\end{tabular}

Fig-4: MPs Conversion per president. Source: Brasil, 2019 [6]

Observe in Figure 4, that the $30^{\text {th }}$ President, Tancredo Neves, passed away on April 21, 1985, and never took office, replaced by José Sarney, from 1985 to 1991 .

President Michel Temer occupied the office for two years and 213 days, due to the Dilma Roussef's impeachment process. The same happened to Fernando Collor, impeached and later substituted for Itamar Franco. Lula da Silva was the president who issued the highest number of MPs converted into Laws. However, both left-wing administrations (Lula's and Dilma's, from Labor Party - PT) were the most corrupt within the entire Brazilian history. Lula is also the only former Brazilian president convicted for corruption, and laundry money, currently in prison, for nine years and six months reclusion.

Michel Temer was the president with the highest number of MPs per term: 4.5 MPs per month, almost one MP per week during his short term.

President Fernando Henrique Cardoso administration (1995-2003), issued the highest number of MPs and reeditions: 422 MPs, plus 9,438 re-editions, totaled 9,860 MPs in eight years mandate.

Finally, President Jair Bolsonaro took office on January 1st, 2019, and cannot be full evaluated because his term has not yet completed a year. So far, twenty MPs were issued by Bolsonaro, and five were converted in Laws, and fifteen are in process, in due time.

\section{PERMANENT MEASURES?}

$\mathrm{N}=51$ Provisory Measures issued before CA 32 are still in force, as illustrated in Figure 5 and 6: 


\begin{tabular}{|c|c|c|c|c|}
\hline$\#$ & MPs & \# Reeditions & In force since & Subject \\
\hline 1 & $2.229-43$ & 41 & 10.09 .2001 & Federal career organization \\
\hline 2 & $2.228-1$ & 1 & 10.09 .2001 & Cinema National Politics (PRODECINE) \\
\hline 3 & 2.227 & 0 & 05.09 .2001 & Alters Law 10.192/01 \\
\hline 4 & 2.226 & 0 & 04.09 .2001 & Adds item to $\mathrm{CLT}$ \\
\hline 5 & 2,225-45 & 44 & 04.09 .2001 & Alter Laws 6.368/76, 8.112/90, 8.429/92, and 9.525/97 \\
\hline 6 & 2.224 & 0 & 04.09 .2001 & Brazilian investments overseas \\
\hline 7 & 2.220 & 0 & 04.09 .2001 & Creation of CNDU - National Development Council \\
\hline 8 & $2.217-3$ & 3 & 01.09 .2001 & $\begin{array}{l}\text { Establishes the National Council for the Integration of Transport Policies, the National Agency of } \\
\text { Land Transport, the National Agency of Waterway Transport and the National Department of } \\
\text { Transport Infrastructure }\end{array}$ \\
\hline 9 & $2.216-37$ & 37 & 01.09 .2001 & Alters Law No. 9,649 of May $27,1998,-$ the organization of the Presidency \\
\hline 10 & $2.215-10$ & 10 & 01.09 .2001 & Military forces salary - Laws 3.765 , and 6.880 \\
\hline 11 & 2.214 & 0 & 01.09 .2001 & Alters o art. 1 o da Lei n o 10.261 - Union budget \\
\hline 12 & $2.213-1$ & 1 & 31.08 .2001 & Creates the Bolsa-Renda program, to assist poor families \\
\hline 13 & 2.211 & 0 & 30.08 .2001 & Alter Law 9.995, and 10.266. Union budget. \\
\hline 14 & 2.210 & 0 & 30.08 .2001 & $\mathrm{R} \$ 50.000 .000,00$ extra credit for Enegy Ministry \\
\hline 15 & 2.209 & 0 & 30.08 .2001 & creation of the Brazilian Trader of Emergency Energy - CBEE \\
\hline 16 & 2.208 & 0 & 20.08.2001 & Provides for proof of student status and under eighteen \\
\hline 17 & $2.206-1$ & 1 & 10.09.2001 & Creates the National Health Minimum Income Program: "Bolsa-Alimentação" \\
\hline 18 & $2.200-2$ & 2 & 27.08.2001 & $\begin{array}{l}\text { Institutes the Brazilian Public Key Infrastructure - ICP-Brasil, transforms the National Institute of } \\
\text { Information Technology into a local authority }\end{array}$ \\
\hline 19 & 2.199-14 & 14 & 27.08.2001 & IR changes on Tax \\
\hline 20 & $2.198-5$ & 5 & 27.08 .2001 & $\begin{array}{l}\text { Creates and installs the Electricity Crisis Management Chamber of the Governing Council, } \\
\text { establishes guidelines for programs to deal with the electric power crisis. }\end{array}$ \\
\hline 21 & $2.197-43$ & 43 & 27.08.2001 & Provides for the adoption of measures related to the Financial System of Housing - SFH \\
\hline 22 & 2.196-3 & 3 & 25.08 .2001 & $\begin{array}{l}\text { Establishes the Program for Strengthening Federal Financial Institutions and authorizes the } \\
\text { creation of the Asset Management Company - EMGEA }\end{array}$ \\
\hline 23 & $2.192-70$ & 70 & 25.08 .2001 & $\begin{array}{l}\text { Establishes mechanisms to encourage the reduction of the state public sector presence in } \\
\text { banking financial activity, provides for the privatization of financial institutions }\end{array}$ \\
\hline 24 & $2.190-34$ & 34 & 24.08.2001 & alters dispotitives on ANVISA - National Sanitary Surveillance Agency \\
\hline 25 & $2.189-49$ & 49 & 24.08 .2001 & $\begin{array}{l}\text { amends income tax legislation with respect to the withholding tax on income from financial } \\
\text { investments, }\end{array}$ \\
\hline 26 & $2.187-13$ & 13 & 27.08.2001 & Provides for the adjustment of benefits maintained by the Social Security \\
\hline 27 & $2.185-35$ & 35 & 27.08.2001 & Refanancing public debt on real estate \\
\hline 28 & $2.184-23$ & 23 & 25.08 .2001 & $\begin{array}{l}\text { ensures perception of gratification by civil servants Federal Police, Federal District Police } \\
\text { Officer, Federal District Civil Police, Federal Highway Police }\end{array}$ \\
\hline 29 & $2.183-56$ & 56 & 27.08.2001 & alter decree 3.365/41, and Laws 4.504/64, 8.177/91, and 8.629/93. \\
\hline 30 & $2.181-45$ & 45 & 27.08 .2001 & Provides for financial transactions between the National Treasury \\
\hline 31 & $2.180-35$ & 35 & 27.08 .2001 & $\begin{array}{l}\text { Alter Laws 8.437/1992, 9.028/95, 9.494/97, 7.347/85, 8.429/92, 9.704/98, Decree 5.452/43, } \\
\text { Laws 5.869/73, and 4.348/64 }\end{array}$ \\
\hline 32 & $2.179-36$ & 36 & 27.08.2001 & Provides for financial relations between the Union and the Central Bank of Brazil \\
\hline 33 & $2.178-36$ & 36 & 25.08 .2001 & $\begin{array}{l}\text { Provides for the transfer of funds from the National School Meals Program, institutes the Direct } \\
\text { Money at School Program, amends Law 9.533/97. }\end{array}$ \\
\hline
\end{tabular}

Fig-5: MPs in process. Source: Brasil, 2019 [6] 


\begin{tabular}{|c|c|c|c|c|}
\hline$\#$ & MPs & \# Reeditions & In force since & Subject \\
\hline 34 & $2.177-44$ & 44 & 27.08.2001 & Amends Law No. 9,656 of June 3,1998, which provides for private health care plans. \\
\hline 35 & $2.174-28$ & 28 & 24.08.2001 & $\begin{array}{l}\text { constitutes, within the scope of the Executive Branch of the Union, the Voluntary Termination } \\
\text { Program - PDV }\end{array}$ \\
\hline 36 & $2.173-24$ & 24 & 24.08.2001 & Provides rules for high school tuition fees \\
\hline 37 & $2.172-32$ & 32 & 24.08.2001 & Establishes the nullity of the contractual provisions \\
\hline 38 & $2.170-36$ & 36 & 24.08 .2001 & Povides for the administration of cash resources of the National Treasury \\
\hline 39 & $2.169-43$ & 43 & 25.08.2001 & $\begin{array}{l}\text { Extends to civil servants of the Federal Executive Branch the advantage of twenty-eight point } \\
\text { eighty six per cent, object of the decision of the Federal Supreme Court }\end{array}$ \\
\hline 40 & $2.168-40$ & 40 & 27.08 .2001 & $\begin{array}{l}\text { Provides for the Agricultural Production Cooperatives Revitalization Program - RECOOP, } \\
\text { authorizes the creation of the National Cooperative Learning Service - SESCOOP }\end{array}$ \\
\hline 41 & $2.167-53$ & 53 & 24.08.2001 & $\begin{array}{l}\text { Authorizes the Union to receive in dividends securities and interest on equity to be paid by } \\
\text { entities in whose capital the National Treasury participates }\end{array}$ \\
\hline 42 & $2.166-67$ & 67 & 25.08 .2001 & Forrestal Code \\
\hline 43 & $2.165-36$ & 36 & 25.08 .2001 & $\begin{array}{l}\text { It establishes the Transport Allowance, provides for the payment of the military and servants of } \\
\text { the Federal Executive Power, including their municipalities, foundations, public companies and } \\
\text { companies of mixed economy. }\end{array}$ \\
\hline 44 & 2.164-41 & 41 & 27.08 .2001 & $\begin{array}{l}\text { Amends the Consolidation of Labor Laws - CLT to provide for part-time work, suspension of } \\
\text { employment contract and professional qualification program }\end{array}$ \\
\hline 45 & 2.163-41 & 41 & 24.08 .2001 & $\begin{array}{l}\text { Provides for criminal and administrative sanctions arising from conduct and activities harmful to } \\
\text { the environment }\end{array}$ \\
\hline 46 & $2.162-72$ & 72 & 24.08 .2001 & $\begin{array}{l}\text { Provides for the issuance of National Treasury Notes - NTN for the capital increase of Banco do } \\
\text { Brasil S.A }\end{array}$ \\
\hline 47 & $2.161-35$ & 35 & 24.08.2001 & amend procedures related to the National Privatization Program \\
\hline 48 & $2.159-70$ & 70 & 27.08.2001 & Amend income tax legislation \\
\hline 49 & $2.158-35$ & 35 & 27.08 .2001 & $\begin{array}{l}\text { Amends the legislation on Social Security Contributions - COFINS, the Social Integration } \\
\text { Programs and the Formation of the Civil Servant Patrimony - PIS / PASEP and the Income Tax }\end{array}$ \\
\hline 50 & 2.157-5 & 5 & 27.08 .2001 & $\begin{array}{l}\text { Creates the Amazon Development Agency - ADA, extinguishes the Amazon Development } \\
\text { Superintendence - SUDAM }\end{array}$ \\
\hline 51 & $2.156-5$ & 5 & 27.08 .2001 & $\begin{array}{l}\text { Creates the Northeast Development Agency - ADENE, extinguishes the Northeast Development } \\
\text { Superintendence - SUDENE }\end{array}$ \\
\hline
\end{tabular}

Fig-6: MPs in process. Source: Brasil, 2019 [6]

Observe in both Figures 5 and 6 the N=51 MPs in process, and currently in force, since 2001. By the original Art. 62 paragraph 1, these MPs should be terminated due to validity extinction. However, CA 32 , on the one hand, decreased the number of MP reeditions substantially to zero. For instance, in Fig-6, the MP 2.159-70 (\#48), was re-issued 70 times and has never been converted into Law, because National Congress did not veto or voted this MP, so far. In sum, what should be temporary became permanent in 51 cases [6], with no further plans for a close appreciation.

\section{DISCUSSION}

Rodrigo Maia, current president of the Chamber of the Deputies, complains the excessive number of MPs, according to him, a clear interference from the Executive in the Legislative branch, locking the Congress agenda:

What I am concerned about is this interference of the Executive Power in the Legislative Power permanently. We have ten provisional measures locking the agenda in the House of Representatives. Too bad you have an agenda that ends up being almost all monopolized by the Executive Power, "said Maia [7].
Given the drastic reduction of Congress activity regarding MPs, due to the CA 32 , it seems an exaggerated commentary. One possible solution for his stalemate should be the reduction of Congress recess period, from the current eight weeks to four weeks, like any Brazilian worker. Brazilian Congressmen shall, at discretion, remain on their bases on Mondays and Fridays, in practice working from Tuesdays to Thursdays. In a developing country like Brazil, this recess embarrasses the population and is a waste of public resources. Congress recesses encompass two periods: July 18th -31 st (14 days) and from December 22nd to February 1st (42 days) [6]. In total, 56 days of recess, or almost two months. Recess should be decreased to 30 days maximum, like any other regular worker. Therefore, Brazilian Congress would be plenty of time to vote all $\mathrm{N}=51 \mathrm{MPs}$ in process, as well as hundreds of Projects of Law and other vital reforms current under plodding appreciation pace by the House of Representatives. Congress members should work the same 44 hours workload, as prescribed for entire urban and rural workers, at least to give an example for the overall Brazilian workers, as worded by Article 7, item XIII from the Brazilian Constitution 1988.

Congressmen should work the same 44 hours workload, as prescribed for entire urban and rural 
workers, at least to give example for the overall Brazilian workers, as worded by Article 7, item XIII from the Brazilian Constitution 1988.

\section{IMPLICATIONS AND FUTURE RESEARCH}

This study implied in revealing potential law insecurity given the provisory measures have become permanent, from which $\mathrm{N}=51$ are in force for 18 years. Critical appreciation of such MPs is paramount for the Brazilian House of Representatives. Another implication is an increasing number of Brazilian business scenarios directly affected by the MPs in process [8-22], for instance.

Future study is recommended to the impact of the $\mathrm{N}=51 \mathrm{MPs}$ in process in lawsuits over the past decades. Congress performance indicators should be applied to appreciate the real impact of MPs to the legislative agenda.

\section{REFERENCES}

1. Yin, R. (1988). Case Study Research: Design and Methods. Newbury Park, CA: Sage Publications.

2. Brasil. (1988). Governo Federal. Constituição da República Federativa do Brasil.

3. de Oliveira Dias, M., \& Teles, A. (2019). A Comprehensive Overview of Brazilian Legislation on Credit Cooperatives. Global Journal of Politics and Law Research, 7(4), 1-12.

4. Brasil. (2001). Medida Provisória 2.168-40/2001 Serviço Nacional de Aprendizagem do Cooperativismo (Sescoop).Autoriza a criação do Sescoop, entidade de direito privado com o objetivo de organizar, administrar e executar o ensino de formação profissional, desenvolvimento e promoção social do trabalhador em cooperativa e dos cooperados.

5. Brasil. (2001). Emenda Constitucional $N^{o} 32$, de 11 de setembro de 2001. Altera dispositivos dos arts. 48, 57, 61, 62, 64, 66, 84, 88 e 246 da Constituição Federal, e dá outras providências. Retrieved from http://www.planalto, on October 16, 2019.

6. Brasil. (2019). Legislação. Retrieved from http://www4.planalto.gov.br/legislacao/portallegis/legislacao-1/medidas-provisorias, on October 16, 2019.

7. Agência, B. (2019). Maia critica excesso de MPs e "interferência permanente" do governo no Congresso. Retrieved from http://agenciabrasil.ebc.com.br/politica/noticia/201 7-11/maia-critica-interferencia-permanente-dogoverno-no-congresso, on October 17, 2019.

8. Dias, M. D. O. (2018). Evolution of Cooperative Societies in Brazil. International Journal of Community and Cooperative Studies, 6(4), 1-11.

9. Dias, M. D. O., \& Craveiro, F. M. (2019). Brazilian Agriculture Cooperative: Vinícola
Aurora Case. International Journal of Management, Technology and Engineering, 9(3), 2551-2561.

10. de Oliveira Dias, M. Krein, J., Streh, E., \& Vilhena, J. B. (2018). Agriculture Cooperatives in Brazil: Cotribá Case. International Journal of Management, Technology And Engineering, 8(12), 2100-2110,

11. Dias, M. D. O., \& Murilo, R. A. R. (2018). Credit Cooperatives in Brazil. International Journal of Science and Research (IJSR), 7(10), 598-603.

12. Dias, M. D. O., \& Teles, A. (2018). Agriculture Cooperatives in Brazil and the Importance for The Economic Development. International Journal of Business Research and Management (IJBRM), 9(2), 72-81.

13. Dias, M. D. O., \& Teles, A. (2019). Credit CoOperatives In Brazil: Sicredi Case. International Journal of Advanced Research, 7(4), 194-202.

14. Dias, M., Aylmer, R., Almeida, R., \& Bulegon, M. (2015). Brazilian Fashion Business Dudalina S/A: Case Revisited. International Journal of Business and Management Studies. ISSN, 2158(1479), 1124.

15. Dias, M., Aylmer, R., Aylmer, M., Almeida, R., \& Bulegon, M. (2014). Dudalina S/A: Case Study on How to Overcome Succession Barriers on a Brazilian Family Business. Business and Management Review, 3(12), 2047-0398.

16. Dias, M., Valle, A., \& Fonseca, A. (2014). FIAT and Chrysler in Brazil: Anatomy of an Alliance. International Journal of Business and Management Studies, 3(1), 2158-1479.

17. Navarro, R., Dias, M., \& Valle, A. (2013). BMW and Brazilian Federal Government: Enhancing the Automotive Industry Regulatory Environment. International Journal of Arts \& Sciences, 6(2), 551-567.

18. Dias, M., Duzert, Y., \& Teles, A. (2019). Boeing, Brazilian Federal Government, And Embraer: Golden Share Veto And The Anatomy Of A Joint Venture. International Journal of Business and Management Studies, CD-ROM; 7(2):71-80.

19. de Oliveira Dias, M., \& Falconi, D. (2018). The Evolution of Craft Beer Industry in Brazil. Journal of Economics and Business, 1(4), 618-626.

20. Dias, M. D. O. (2018). Heineken Brewing Industry in Brazil. International Journal of Management, Technology and Engineering (IJAMTES), 13041310.

21. Dias, M., \& Davila Jr, E. (2018). Overcoming Succession Conflicts in a Limestone Family Business In Brazil. International Journal of Business and Management Review, 6(7), 58-73.

22. Dias, M. (2016). Factors Influencing the Success of Business Negotiations in the Brazilian Culture (Doctoral Thesis). ESC Rennes School of Business, France. 